\title{
DIAGNOSIS JENIS PENYAKIT TANAMAN JATI (Tectona Grandis) PADA AREAL HUTAN TANAMAN DESA HATUSUA KECAMATAN KAIRATU KABUPATEN SERAM BAGIAN BARAT
}

\author{
Jogeneis Patty) ${ }^{1}$, Costanza Uruilal) ${ }^{2}$ \\ Program Studi Agroekoteknologi Jurusan Budidaya Pertanian Fakultas Pertanian Universitas Pattimura Ambon \\ Jl. Ir.M. Putuhena, Kampus Unpatti Poka, Ambon-Kode Pos 97233 \\ Telepon/Faximili: (0911) 322499. (0911) 322498 \\ Korespondensi Email : huwaepatty@yahoo.co.id
}

Diterima pada : 10 Juli 2016 Disetujui pada : 09 September 2016

\section{Intisari}

Pengembangan hutan tanaman Jati di Desa Hatusua Kecamatan Kairatu Kabupaten Seram Bagian Barat merupakan salah satu upaya untuk mengimbangi kebutuhan akan bahan baku kayu yang semakin meningkat. Namun berdasarkan pengamatan pendahuluan terlihat adanya gejala serangan penyakit seperti penyakit bercak daun. Dengan demikian perlu dilakukan diagnosis terhadap jenis-jenis penyakit pada areal hutan tersebut. Penelitian bertujuan untuk mengetahui jenis-jenis penyakit yang menyerang tanaman jati (Tectona. grandis) pada areal hutan tanaman Desa Hatusua Kecamatan Kairatu Kabupaten Seram Bagian Barat, menentukan intensitas penyakit serta tingkat kerusakannya, serta mengetahui kondisi areal pertanaman jati yang menunjang perkembangan penyakit. Hasil penelitian menunjukkan bahwa jenis-jenis penyakit yang ditemukan adalah penyakit bercak daun yang disebabkan oleh jamur Phomopsis sp. dan penyakit busuk akar dan pangkal batang yang merupakan gejala penyakit fisiologis. Intensitas penyakit bercak adalah 16,21 $\%$ serta intensitas penyak busuk akar dan pangkal batang 10,08 \%, keduanya tergolong kategori serangan ringan. Kondisi areal hutan tanaman Jati Desa Hatusua cukup menunjang perkembangan penyakit.

Kata kunci: Tectona grandis, Bercak Daun, Busuk Akar dan Pangkal Batang Phomopsis sp., Penyakit Fisiologis

\begin{abstract}
Teak plantation forest development in the village Hatusua Kairatu District of West Seram regency is one attempt to offset the need for wood raw material increases. However, based on preliminary observations visible symptom of diseases such as leaf spot disease. Thus the need to do a diagnosis of the types of diseases in the forest area.The study aims to determine the types of diseases that attack plants teak (Tectona grandis) in the plantation areas Hatusua Rural District of West Seram regency Kairatu, determine the intensity of the disease as well as the extent of the damage and determine the condition of the teak plantations and support the development of the disease.The results showed that the types of diseases that are found is a leaf spot disease caused by the fungus Phomopsis sp. and root rot and stem are a symptom of a physiological disease. The disease intensity of leaf spot was 1,21\% and the disease intensity of root and stem rot 10,08\%, both of which belong to the category of minor assault. Conditions in the village area of teak plants Hatusua support the development of the disease.
\end{abstract}

Keywords: Tectona grandis, Leaf Spot, Root and Stem Rot, Phomopsis sp., Physiological Disease 


\section{PENDAHULUAN}

Hutan mempunyai kedudukan dan peranan yang sangat penting dalam menunjang pembangunan nasional, hal ini disebabkan hutan dapat memberikan manfaat yang sebesar-besarnya bagi kemakmuran dan kesejahteraan rakyat.

Jati (Tectona grandis Linnaeus filius) merupakan jenis tanaman yang telah dikembangkan kurang lebih 100 tahun yang lalu di Pulau Jawa sebagai hutan tanaman yang hingga tahun 1991 telah mencapai 1,5 juta Ha (Poerwidodo, 1991 dalam Irwanto, 2003). Seiring dengan perjalanan waktu dan kebutuhan manusia akan bahan baku kayu Jati yang selalu meningkat sedangkan daur produksi dari tanaman ini cukup lama yaitu baru berproduksi setelah umur 60 tahun, sedangkan produksi optimumnya pada umur 80 tahun mengakibatkan ketersediaan Jati yang semula melimpah di hutan semakin terbatas (Yana Sumarna, 2003). Namun dengan adanya perkembangan ilmu pengetahuan dan teknologi dalam bidang pemuliaan tanaman mampu menciptakan tanaman Jati yang dapat dipanen lebih cepat dibandingkan tanaman Jati biasa yang disebut dengan nama Jati unggul. Hal ini menyebabkan tanaman ini mulai banyak dibudidayakan (Zain, 1998).

Selain memiliki laju pertumbuhan yang cepat, Jati juga sering diidentikan dengan tanaman yang memiliki ketahanan tinggi terhadap serangan penyakit, namun ini bukan berarti Jati unggul tidak berisiko terserang penyakit. Hal ini disebabkan hampir tidak ada lahan penanaman Jati baik berupa kebun maupun hutan yang sama sekali terbebas dari populasi penyakit. Dalam kenyataannya tanaman Jati sering mengalami kerusakan akibat serangan penyakit sehingga menyebabkan penurunan kualitas dan kuantitas hasil. Tanaman atau pohon disebut sakit apabila timbul gejala atau tanda kerusakan pada bagian tanaman. Bisa juga tanaman tersebut tumbuh secara tidak normal yang mengakibatkan produksinya mengalami kemunduran, bahkan mengalami kematian (Nia Tini dan Khairul Amri, 2002).

Berdasarkan permasalahan diatas maka upaya penanggulangan penyakit pada suatu areal pertanaman tertentu harus dilakukan sedini mungkin sehingga tingkat kerusakannya dapat ditekan. Diagnosis penyakit harus dilakukan sebagai langkah awal dalam mengetahui jenis penyakit yang menyerang dan tingkat kerusakannya sehingga diterapkan metode pencegahan maupun pengendalian secara tepat.

Pengembangan hutan tanaman Jati di Desa Hatusua Kecamatan Kairatu Kabupaten Seram Bagian Barat merupakan salah satu upaya untuk mengimbangi kebutuhan akan bahan baku kayu yang semakin meningkat. Namun berdasarkan pengamatan pendahuluan terlihat adanya gejala serangan penyakit seperti penyakit bercak daun. Dengan demikian perlu dilakukan diagnosis terhadap jenis-jenis penyakit yang ada pada areal hutan tersebut, sehingga diketahui penyebab penyakit dan kerusakan yang ditimbulkan.

Data-data tersebut sangat berguna dalam penetapan tindakan pencegahan dan pengendalian penyakit, sehingga diharapkan dapat meminimalisasi kerusakan tanaman yang ditimbulkan akibat serangan penyakit, untuk mempertahankan kualitas dan kuantitas hasil tegakan jati tersebut.

Penelitian bertujuan untuk mengetahui jenisjenis penyakit yang menyerang tanaman jati ( $T$. grandis) pada areal hutan tanaman Desa Hatusua Kecamatan Kairatu Kabupaten Seram Bagian Barat, menentukan intensitas penyakit serta tingkat kerusakan dari masing-masing jenis penyakit dan mengetahui kondisi areal pertanaman jati yang menunjang perkembangan jenis-jenis penyakit.

\section{METODE PENELITIAN}

Penelitian meliputi penelitian lapangan dan penelitian laboratorium, penelitian lapangan dilaksanakan di areal Hutan Tanaman Jati (T. grandis) Desa Hatusua Kecamatan Kairatu Kabupaten Seram Bagian Barat, pada bulan Oktober 2015 kemudian dilanjutkan dengan penelitian Laboratorium pada Laboratorium Penyakit Tumbuhan Fakultas Pertanian Universitas Pattimura Ambon pada bulan Januari sampai Februari 2016.

Alat-alat yang digunakan yakni mikroskop binokuler, Laminar Air Flow, autoclave, oven, gelas objek, cawan Petri, pipet, thermohigrometer, kamera digital, pisau, loup, alat tulis menulis. Bahan-bahan 
yang digunakan adalah bagian tanaman hutan yang menunjukan gejala penyakit tertentu, media PDA (Potato Dextrose Agar), kantong plastik, selotip, air steril, metilen biru, alkohol $90 \%$, kapas, tisu, dan alumunium foil.

Penelitian bersifat deskriptif menggunakan metode survei pada empat areal tegakan jati diDesa Hatusua luas masing - masing areal sebagai berikut: areal I seluas $3,600 \mathrm{~m}^{2}$, areal II seluas $2,592 \mathrm{~m}^{2}$, areal III seluas $3,960 \mathrm{~m}^{2}$ dan areal IV dengan luas $3,960 \mathrm{~m}^{2}$. Pada setiap areal dibagi lagi menjadi 5 petak sampel yang ditetapkan secara sistematik (Sistematic random sampling) dengan ukuran petak $10 \mathrm{~m} \times 10 \mathrm{~m}$. Tanaman sebanyak $10 \%$ dari populasi tanaman yang tumbuh dalam areal, sehingga untuk areal I memiliki jumlah pohon sebanyak 651 pohon ditetapkan 65 pohon sampel yang tersebar pada 5 petak (pada masing-masing petak diambil 13 pohon sampel). Areal II dengan jumlah pohon sebanyak 481 pohon diambil 50 pohon sebagai sampel yang tersebar pada 5 petak (pada masing-masing petak diambil 10 pohon sampel). Untuk areal III dan IV jumlah pohon pada masing-masing areal berjumlah 713 pohon, diambil 71 pohon sebagai sampel yang tersebar pada 5 petak (pada masing-masing petak diambil 14 pohon sampel).

Data yang diambil meliputi data primer dan data sekunder. Data primer meliputi gambaran gejala dan tanda penyakit, intensitas penyakit, tingkat kerusakan, jarak tanam, luas areal, jumlah tanaman dan kondisi areal. Penetapan intensitas penyakit yang menunjukan gejala lokal didekati dengan rumus dari Natawigena (1982) dalam Sugiharso (1988) sebagai berikut:

$$
\mathrm{IP}=\frac{\sum(n \times v)}{\mathrm{Z} \times \mathrm{N}} \times 100 \%
$$

Keterangan IP $=$ Intensitas penyakit per tanaman.

$$
\begin{aligned}
n= & \text { Jumlah ranting dari tiap kategori } \\
& \text { serangan. } \\
v= & \text { Nilai skala dari tiap kategori } \\
& \text { serangan. } \\
\mathrm{Z}= & \text { Nilai skala yang ditetapkan } \\
& \text { tertinggi (4) }
\end{aligned}
$$

Penentuan nilai skala didasarkan pada setiap gambaran gejala penyakit dari kategori serangan penyakit tercantum pada Tabel 1 .

Tabel 1. Nilai Skala Yang Didasarkan Pada Gambaran Gejala dan Kategori Serangannya.

\begin{tabular}{ccc}
\hline $\begin{array}{c}\text { Nilai } \\
\text { Skala }\end{array}$ & Gambaran Gejala Penyakit & $\begin{array}{c}\text { Kategori } \\
\text { Serangan }\end{array}$ \\
\hline 0 & Tidak tampak gejala penyakit & Sehat \\
1 & $>0-25 \%$ bagian tanaman sakit & Ringan \\
2 & $>25-50 \%$ bagian tanaman sakit & Sedang \\
3 & $>50-75 \%$ bagian tanaman sakit & Berat \\
4 & $>75 \%$ bagian tanaman sakit & Sangat Berat \\
\hline
\end{tabular}

Penentuan intensitas penyakit yang menunjukan gejala sistemik didekati dengan rumus dari Natawigena (1982) dalam Sugiharso (1988)sebagai berikut:

$$
\mathrm{IP}=\frac{a}{a+b} \times 100 \%
$$

Keterangan $\quad \mathrm{IP}=$ Intensitas penyakit per petak.

$a$ = Jumlah tanaman sakit.

$b=$ Jumlah tanaman sehat.

Data sekunder yang diambil yakni suhu udara dan kelembababan udara mikro, sedangkan intensitas penyinaran matahari dan curah hujan terakhir diperoleh dari Stasiun Meterologi dan Geofisika Kecamatan Kairatu.

Penelitian laboratorium dimaksudkan untuk mengidentifikasi penyebab penyakit yang ditemukan. Bagian tanaman (daun, akar, dan batang), yang menunjukan gejala penyakit diambil dimasukan dalam kantong plastik dilakukan isolasi. Metoda yang digunakan adalah isoalasi jaringan tanaman sakit (Plant Tissue Method) pada media PDA (Potato Dextrose Agar) (Dhingra dan Sinclair, 1986). Koloni patogen yang tumbuh dimurnikan kemudian diamati secara mikroskopik dengan pembesaran total 400 kali dan hasil pengamatan diidentifikasi berdasarkan kunci indentifikasi Alexopoulus dan Mims (1979) dan Barnet (1980). 


\section{HASIL DAN PEMBAHASAN}

\section{Penyakit Bercak Daun}

Penyakit bercak daun ditunjjukan dengan gambar berupa bercak cokelat keabu-abuan dengan bentuk yang tidak beraturan, bercaknya tersebar pada bagian tengah daun dan pada pinggiran daun (Gambar 1).
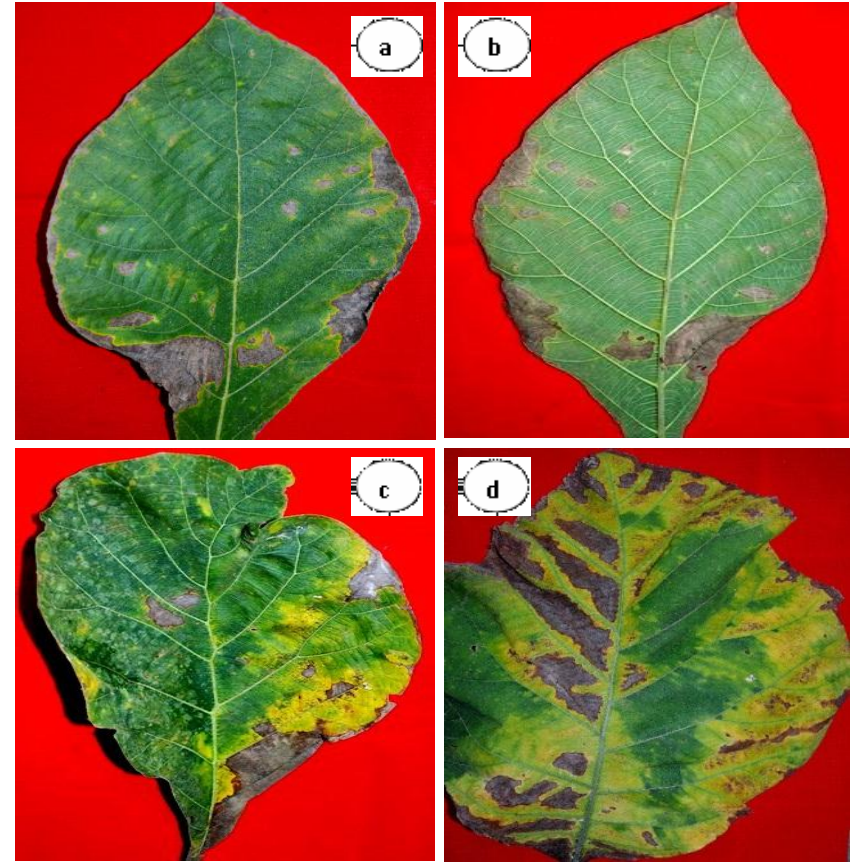

Gambar 1. Gejala Penyakit Bercak Daun Jati ( $\mathrm{a}=$ Gejala bercak daun dilihat dari sisi atas daun; $b=$ gejala bercak dilihat dari sisi bawah daun; $\mathrm{c}$ dan $\mathrm{d}=$ gejala bercak disertai perubahan warna daun menjadi kekuningan)

Beberapa bercak kecil dalam satu daun dapat menyatu membentuk daerah bercak yang besar seperti terlihat pada pinggiran daun. Hal ini sesuai dengan pendapat Anggraeni dan Suharti (1996).

Berdasarkan hasil pengamatan, terlihat bahwa gejala penyakit bercak daun lebih banyak terjadi pada daun-daun tua dibandingkan dengan daundaun muda. Infeksi yang terjadi pada jaringan daun secara langsung akan mempengaruhi proses fotosintesis dan tentunya akan berdampak negatif terhadap pertumbuhan tanaman.

Rukmana dan Saputra (2001) mengemukakan bahwa penyebab penyakit bercak daun dapat melakukan penetrasi pada jaringan tanaman melalui stomata (mulut daun), kemudian masuk dalam konidium jamur tersebut dipancarkan oleh angin dan serangga, meskipun angin memegang peranan jauh lebih besar. Infeksi dapat terjadi melalui kedua sisi daun, tetapi paling banyak melalui epidermis atas.

Berdasarkan hasil penelitian laboratorium, penyebab penyakit bercak daun jati adalah jamur Phomopsis sp., dengan ciri-ciri morfologinya sebagai berikut: konidium tidak bersepta, hialin, dan filiform, sedangkan konidiofor memiliki percabangan, filiform, dan hialin. Ciri-ciri ini sesuai dengan ciri-ciri jamur tersebut yang dikemukakan oleh Alexopoulus dan Mims (1979) yakni konidia Jamur Phomopsis sp tidak bersepta, filiform, dan hialin dengan ukuran 10.5 - 18 x $1 \mathrm{~mm}$, sedangkan konidiofor memiliki percabangan, filiform, dan hialin.

\section{Penyakit Busuk Akar dan Pangkal Batang}

Gejala penyakit pada pangkal batang tanaman jati merupakan kerusakan fisiologis yang disebabkan karena kondisi areal tanaman jati yang tergenang air. Hal ini hanya terlihat pada tanamantanaman yang berada pada genangan air akibat hujan. Kondisi tanah dengan drainase yang buruk di musim hujan menyebabkan bagian perakaran dan pangkal batang tanaman membusuk. Apabila kondisi drainase areal tanaman tidak diperbaiki, dapat menyebabkan kerusakan yang lebih luas pada bagian akar dan pangkal batang (Gambar 2).

\section{Gambar 2. Gejala Penyakit Busuk Akar dan Pangkal}

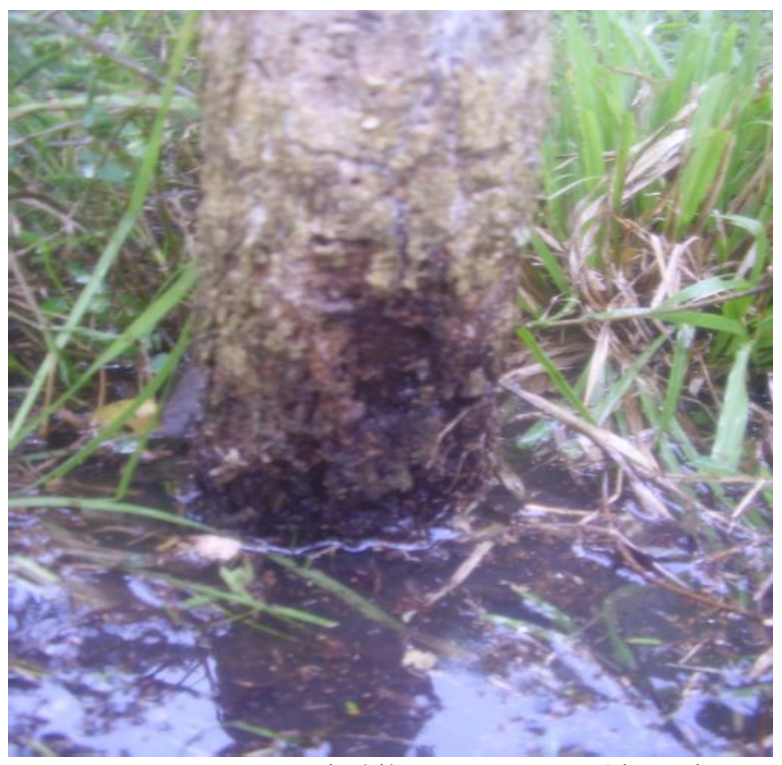

Batang Tanaman Jati akibat Tergenang Air Hujan 
Drainase yang buruk menyebabkan tanaman Jati kehilangan vigor, yang akan diikuti oleh gejala kelayuan dan perubahan warna daun menjadi hijau pucat atau hijau kekuningan. Bila tanaman Jati yang diserang penyakit layu dicabut dan dilihat perakarannya, jaringan xylem dan floem terlihat berwarna hitam gelap sedangkan batang dekat permukaan tanah dan akar tunggang menjadi lunak dan basah.

Drainase yang buruk menyebabkan tumbuhan kehilangan vigor, seringkali diikuti oleh gejala kelayuan dan oleh perubahan warna daun menjadi hijau pucat atau hijau kekuningan. Kelebihan air pada saat fase pertumbuhan seringkali menyebabkan gejala kelayuan permanen dan kematian jaringan-jaringan muda sukulen. Sebagai akibat kelebihan air karena banjir atau drainase yang buruk, akar tumbuhan membusuk yang dapat disebabkan oleh kurangnya ketersediaan oksigen bagi akar. Keterbatasan oksigen menyebabkan cekaman seperti tercekik atau kehabisan nafas (asphyxiation) dan kerusakan sel-sel akar. Kondisi yang basah dan anaerobik dapat mndorong terbentuknya senyawa yang dapat meracuni tumbuhan seperti nitrit. Sel-sel akar yang rusak kehilangan sifat permeabilitas selektifnya dan menyebabkan unsurunsur logam atau senyawa beracun lain terserap oleh akar tumbuhan.

\section{Kondisi Areal}

Tegakan Jati dalam areal pengamatan memiliki tingkat umur yang sama yakni 4 tahun. Jarak tanam yaitu $2 \mathrm{~m}$ Í $3 \mathrm{~m}$. Tanaman-tanaman yang ditemukan di sekitar areal adalah Samama, Lenggua, Ketapang, Gondal, Bambu, Kelapa, Mayang, Mangga, Sukun, Kayu Waru, Kayu Asam, Kayu Raja, Jambu Mete dan Cengkeh. Pada setiap areal umumnya ditumbuhi oleh gulma alangalang dan sungga-sungga yang merupakan dominan.
Tabel 2. Kondisi Areal Hutan Tanaman Jati Desa Hatusua Kecamatan Kairatu Kabupaten Seram Bagian Barat

\begin{tabular}{|c|c|c|c|}
\hline \multicolumn{3}{|c|}{ Areal Topografi ${ }^{\text {Jenis Tanaman }}$} & Kondisi Areal \\
\hline I & Datar & $\begin{array}{l}\text { Kelapa, Kayu } \\
\text { Waru, Kayu } \\
\text { Asam, Bambu, } \\
\text { Gondal, Jambu } \\
\text { Mete, dan } \\
\text { Cengkeh. }\end{array}$ & $\begin{array}{l}\text { Areal kurang terawat } \\
\text { dan banyak ditumbuhi } \\
\text { gulma. Pada petak } \\
\mathrm{V} \text {, air tertampung } \\
\text { di sekitar perakaran } \\
\text { tanaman. }\end{array}$ \\
\hline II & Datar & $\begin{array}{l}\text { Samama, } \\
\text { Bambu, dan } \\
\text { Kayu Raja. }\end{array}$ & $\begin{array}{l}\text { Areal kurang terawat } \\
\text { dan banyak ditumbuhi } \\
\text { gulma. Pada petak } \\
\text { II, air tertampung } \\
\text { di sekitar perakaran } \\
\text { tanaman. }\end{array}$ \\
\hline III & Datar & $\begin{array}{l}\text { Sukun, Kelapa, } \\
\text { Mangga, dan } \\
\text { Bambu. }\end{array}$ & $\begin{array}{l}\text { Areal kurang terawat } \\
\text { dan banyak ditumbuhi } \\
\text { gulma. Pada petak } \\
\text { V, air tertampung } \\
\text { di sekitar perakaran } \\
\text { tanaman dan } \\
\text { membentuk rawa. }\end{array}$ \\
\hline IV & Datar & $\begin{array}{l}\text { Kelapa, } \\
\text { Mayang, } \\
\text { Mangga, } \\
\text { Gondal, dan } \\
\text { Lenggua. }\end{array}$ & $\begin{array}{l}\text { Areal kurang terawat } \\
\text { dan banyak ditumbuhi } \\
\text { gulma. Pada petak } \\
\text { I, IV dan V air } \\
\text { tertampung di sekitar } \\
\text { perakaran tanaman } \\
\text { dan membentuk rawa. }\end{array}$ \\
\hline
\end{tabular}

Secara umum areal penelitian berpeluang untuk menunjang terjadinya penyakit seperti kondisi areal yang kurang terawat dan gulma yakni dibiarkan tumbuh. Gulma yang tumbuh dominan pada lokasi tersebut adalah sungga-sungga, alang-alang, putri malu dan rumput teki. Gulma yang dibiarkan tumbuh di sekitar tanaman hutan akan menyebabkan persaingan dalam memperoleh air dan unsur-unsur hara, apalagi pemupukkan dilakukan hanya satu kali yaitu pada awal penanaman. Hal ini menyebabkan tanaman kurang mendapat pasokan nutrisi dan menjadi lemah, sehingga lebih mudah terserang patogen yang tergolong parasit lemah seperti bercak daun. Selain itu gulma juga merupakan salah satu inang perantara bagi penyebab penyakit. 
Selain itu, kondisi areal hutan tanaman jati juga memiliki kelembapan yang relatif tinggi ( 75 - $80 \%$ ). Hal ini dikarenakan selain adanya gulma dan serasah, juga adanya sistem drainase yang kurang baik terbukti dengan adanya genangan air pada beberapa petak membentuk rawa-rawa kecil. Kondisi tersebut dapat memacu perkembangan penyakit. Tanaman Jati merupakan tanaman yang tidak dapat bertahan terhadap kondisi tanah dengan kelembapan yang tinggi. Hal ini akan menyebabkan tanaman dalam kondisi lemah dan rentan sehingga mudah terserang patogen. Inokulum dari patogen akan selalu bertahan pada daun-daun atau bagian tanaman yang sakit, karena tidak pernah dilakukan sanitasi bagian tanaman yang sakit, menyebabkan siklus patogen selalu ada untuk menginfeksi tanaman.

\section{Intensitas Penyakit}

Intensitas penyakit tanaman Jati pada areal Hutan Tanaman Desa Hatusua tercantum pada Tabel 3.

Intensitas penyakit bercak daun memiliki intensitas penyakit tertinggi yaitu 16,21\%, sedangkan penyakit busuk akar dan pangkal batang memiliki intensitas penyakit lebih rendah yaitu $10,08 \%$, namun kedua jenis penyakit tersebut tergolong dalam kategori serangan ringan.
Berdasarkan hasil analisis data pada Tabel 3, terlibat rata-rata intensitas penyakit bercak daun sebesar $16,21 \%$ dan tergolong kategori serangan ringan. Intensitas penyakit tersebut merupakan jumlah rata-rata dikeempat titik pengamatan. Areal I, II dan IV tergolong kategori serangan ringan dengan intensitas penyakit masing-masing yaitu sebesar $14,33 \%, 12,91 \%$ dan 13,42\%. Sedangkan areal III dengan intensitas penyakit tertinggi sebesar $24,19 \%$ dan tergolong dalam kategori serangan ringan.

Walaupun nilai intensitas penyakit bercak daun masihtergolongringandantidakmematikantanaman, namun perlu dilakukan tindakan pengendalian. Hal ini dikarenakan penyakit bercak daun dapat mempengaruhi proses fotosintesis yang berdampak terhadap pertumbuhan tanaman. Langkah-langkah pencegahan dan pengendalian seperti melakukan sanitasi terhadap gulma, dan perdu seperti sunggasungga. Selain itu perlu dilakukan monitoring kondisi tanaman, dan pemupukan tambahan.

\section{KESIMPULAN DAN SARAN}

Berdasarkan hasildan pembahasan dapat disimpulkan sebagai berikut: 1) jenis-jenis penyakit yang ditemukan pada tanaman Jati (T. grandis) di areal hutan tanaman Desa Hatusua adalah penyakit bercak daun yang disebabkan oleh jamur Phomopsis

Tabel 3. Intensitas Penyakit Tanaman Jati pada Areal Hutan Tanaman Desa Hatusua Kecamatan Kairatu Kabupaten Seram Bagian Barat

\begin{tabular}{lccccc}
\hline \multirow{2}{*}{ Jenis Penyakit } & \multicolumn{5}{c}{ Intensitas Penyakit (\%) dan Kategori Serangan } \\
\cline { 2 - 6 } & Areal & Areal & Areal & Areal & Rata-rata \\
\cline { 2 - 6 } Bercak Daun & I & II & III & IV & Kategori \\
\cline { 2 - 6 } & 14,33 & 12,91 & 24,19 & 13,42 & 16,21 \\
& Kategori & Ringan & Ringan & Ringan & Ringan \\
& Ringan & & & & \\
\hline \multirow{2}{*}{$\begin{array}{l}\text { Akar dan Pangkal } \\
\text { Batang }\end{array}$} & 4,70 & 3,33 & 17,67 & 14,63 & 10,08 \\
\cline { 2 - 6 } & Kategori & Kategori & Kategori & Kategori & Kategori \\
& Ringan & Ringan & Ringan & Ringan & Ringan \\
\hline
\end{tabular}


sp. dan penyakit busuk akar dan pangkal batang yang merupakan gejala penyakit fisiologis; 2) intensitas penyakit bercak daun tanaman jati di Desa Hatusua adalah 16,21 \% serta intensitas penyakit busuk akar dan pangkal batang 10,08 $\%$, keduanya masih tergolong kategori serangan ringan; dan 3) kondisi areal hutan tanaman Jati Desa Hatusua cukup menunjang perkembangan penyakit. Kendala yang ditemui dilapanngan dapat diminimalisasi dengan melakukan usaha-usaha pemeliharaan tanaman guna mencegah meluasnya perkembangan penyakit, diantaranya monitoring secara teratur dan pemupukan tambahan; 2) gulma yang tumbuh di sekitar areal pertanaman, perlu dibersihkan secara rutin sehingga tidak terjadi persaingan dengan tanaman jati dalam memperoleh air dan unsur hara.

\section{DAFTAR PUSTAKA}

Alexopoulus, C. J. and C. W. Mims, 1979. Introductory Mycology. Third Edition, Jhon Wiley and Sons, New York Chishester, Brisben, Toronto.

Barnet, H. L., 1980. Illustrated Genera Of Imperfecty Fungi, Second Edition. Burgess Publish Company. Departemen Of Plant Pathology, Bacteriology, and Entomology. West Virginia University, Morgantown, West Virginia.
Dhingra dan Sinclair, 1986. Basic Plant Pathology Methods, CRC. Press, Tokyo

Irwanto, 2003. Pengaruh Rootone-F dan Ukuran Diameter Stek Terhadap Keberhasilan Stek Batang Jati (Tectona grandis Linnaeus filius). Jurusan Kehutanan Fakultas Pertanian Universitas Pattimura (Penelitian).

Irwanto, 2006. Usaha Pengembangan Jati (Tectona grandis Linnaeus filius) dalam http://www. irwantoshut.com.

Nia Tini dan Khairul Amri, 2002. Kiat Mengatasi Permasalahan Praktis "Mengebunkan Jati Unggul” Pilihan Investasi Prospektif. PT. Agro Media Pustaka. Jakarta

Salim H. S. 2003. Budidaya Jati. PT. Penebar Swadaya. Jakarta.

Sugiharso, S. 1988. Dasar Perlindungan Tanaman. Departemen Perlindungan Ilmu Hama dan Penyakit Tumbuhan, Faperta, Bogor.

Yana Sumarna, 2003. Budi Daya Jati. Penerbit Penebar Swadaya. Jakarta.

Zain, 1998. Aspek Pembinaan Kawasan Hutan dan Stratifikasi Hutan Rakyat. Penerbit Rineka Cipta. Jakarta. 